\title{
UPAYA PEMBERIAN PELAYANAN PUBLIK DI UPT PUSKESMAS BALAI MAKAM KABUPATEN BENGKALIS
}

\author{
Dedy Afrizal, Nahar Effendi, Pertiwi Handayani \\ Sekolah Tinggi Ilmu Administrasi Lancang Kuning Dumai \\ e-mail: dedy_keju@yahoo.co.id
}

\begin{abstract}
Public services provided by service providers must be synchronized with act no. 25 of 2009 on public services in which there are stipulation of services, goods services, and administrative services for the society. The technical services unit (upt) of the puskesmas balai makam subdistrict of bathin solapan, bengkalis regency is a type of non-inpatient puskesmas under the supervision of the bengkalis district health service that provides services to the society, especially health services, however the facilities and infrastructure are not well implemented, payment system is not in accordance with the standard, and the problem of lack of availability of medicines for people who need health services. This study will elaborate the conduct of the services at how the implementation of services, supporting factors and inhibiting factors of health services. The result of the study will refer to the implementation of 5 indicators such as tangibles, reliability, responsiveness, assurance, emphaty are obtained a total score of 3,974 (88.31\%) for the good category.
\end{abstract}

Keywords: Service, Public Service, Puskesmas

\begin{abstract}
Abstrak
Pelayanan publik yang diberikan oleh pihak penyelenggara pelayanan tentunya sesuai dengan peraturan yang berlaku sesuai dengan undang-undang pelayanan publik no. 25 tahun 2009 yang didalamnya terdapat pelayanan barang, pelayanan jasa dan pelayanan administrasi untuk masyarakat. Unit pelayanan teknis (upt) puskesmas balai makam kecamatan bathin solapan kabupaten bengkalis merupakan type puskesmas non rawat inap dibawah supervisi dinas kesehatan kabupaten bengkalis yang memberikan pelayanan kepada masyarakat terutama pelayanan kesehatan dimana dalam pelaksanaanya masih belum maksimalnya pemenuhan sarana dan prasarana pelayanan kesehatan, ditemukannya pembayaran yang belum sesuai dengan standar yang ditetapkan serta serta masih belum lengkapnya pemenuhan ketersediaan obat-obatan yang diperlukan bagi kebutuhan masyarakat yang melakukan pelayanan kesehatan. Kajian ini akan melihat bagaimana pelaksanaan pelayanan dan faktor pendukung serta faktor penghambat dalam pemberian pelayanan kesehatan. Hasil dari penelitian pelaksanaan terhadap 5 (lima) indikator yaitu, tangibles, reliability, responsiveness, assurance, emphaty diperoleh total skor 3.974 (88,31\%) berada pada kategori baik.
\end{abstract}

Kata Kunci : Pelayanan, Pelayanan Publik, Puskesmas 


\section{PENDAHULUAN}

Tanggung jawab pemerintah dalam memberikan pelayanan publik untuk masyarakat dilakukan dari pusat hingga daerah sesuai dengan undang-undang nomor 25 tahun 2009 tentang pelayanan publik. Pelayanan ialah kegiatan yang dilakukan oleh birokrasi publik untuk memenuhi semua kebutuhan warga negara yang membutuhkan layanan publik. (dwiyanto, 2014). Dibutuhkannya birokrasi yang profesional yang menjadi syarat penting untuk mewujudkan kualitas pelayanan publik (Arifin \& Abidin, 2019), (afrizal, 2018), (Rijal, F., Dangnga, M. S., Usman, 2019). Pendapat yang sama juga dipaparkan dimana pelayanan ialah bagaimana cara seseorang melayani, membantu menyediakan, dan mengelola dan melengkapi semua persyaratan untuk seseorang atau sekelompok orang. (Afrizal \& Sahuri, 2012). Dalam penelitian pelayanan kerap menggunakan tangibles, reliability, responsiveness, assurance, emphaty (Parasuraman, Zeithaml, \& Berry, 1994). Indikator tersebut dikenal dengan 5 indokator pelayanan publik dan digunakan dalam melihat pelayanan publik dan mengukur pelayanan publik seperti penelitian (Rijal, F., Dangnga, M. S., Usman, 2019), (Lowokwaru, Malang, \& Widodo, 2019), (Sari, 2019).

Pelayanan publik merupakan sebuah rangkaian kegiatan memenuhi pelayanan oleh pihak penyelenggara pelayanan yang diberikan sesuai dengan peraturan yang berlaku kepada warga negara yang didalamnya terdapat pelayanan barang, pelayanan jasa dan pelayanan administrasi. Hal ini tentunya dalam upaya memaksimalkan pelayanan publik yang diberikan oleh pemerintah agar terciptanya perasaan puas dari masyarakat (hermanto, 2018). Salah satu bentuk pelayanan yang diberikan ialah pelayanan publik yang berkualitas (afrizal \& sahuri, 2012), (afrizal, 2018) dimana mengatakan bahwa kualitas dari layanan ialah kegiatan yang menimbulkan rasa puas terhadap pelayanan yang diberikan kepada masyarakat. Rasa puas tersebut menjadi indokator dari kinerja sebuah organisasi publik. Puskesmas merupakan organisasi publik yang memberikan pelayanan kesehatan yang menjadi kebutuhan masyarakat guna pencapaian kesejahteraan masyarakat (Rijal, F., Dangnga, M. S., Usman, 2019), (Sari, 2019).

Upaya-upaya yang dilakukan organisasi publik dibidang kesehatan saat ini yang dilakukan ialah dengan perbaikan-perbaikan dari sisi pelayanan kesehatan. (Regah, R. T., Sabijono, H., \& Pinatik, 2019) mengatakan bahwa pelayanan kesehatan merupakan pelayanan yang tergolong dalam pelayanan kedokteran (Medical Service) yang dapat diberikan secara sendiri (Solo Practice) atau secara bersama dalam suatu organisasi yang bertujuan untuk menyembuhkan penyakit dan membantu dalam pemulihan kesehatan baik secara perorangan maupun masyarakat banyak (Sari, 2019). Hal ini juga terlihat upaya pemerintah dalam mencapai peningkatan kesehatan masyarakat secara maksimal tentunya dimulai dari penyelenggaraan kesehatan di level bawah yang tersebar di indonesia saat ini yang disebut pusat kesehatan masyarakat (puskesmas) dimana menurut Peraturan Menteri Kesehatan Republik Indonesia Nomor 75 Tahun 2014 (Permenkes, R.I , 2014). Menyatakan bahwa puskesmas dibuat sebagai suatu fasilitas dalam upaya memberikan pelayanan kesehatan untuk perorangan maupun masyarakat guna mencapai drajat kesehatan yang tinggi. Serta pelayanan yang diberikan dituntut untuk memuaskan masyarakat sebagai pasien sesuai dengan standar yang telah ditetapkan.

Unit pelayanan teknis (UPT) Puskesmas Balai Makam Kecamatan Bathin Solapan Kabupaten Bengkalis merupakan type puskesmas non rawat inap dibawah supervisi Dinas Kesehatan Kabupaten Bengkalis. Pelayanan yang diberikan berdasarkan Keputusan Bupati Bengkalis Nomor 75 Tahun 2016 Tentang Jenis Pelayanan Kesehatan Dasar Unit Pelaksana Teknis Puskesmas Dan Jaringannya Diwilayah Kabupaten Bengkalis. Berikut jenis pelayanan kesehatan dan jumlah kunjungan internal pasien sebagai berikut: 
Tabel 1 : Jenis Pelayanan Dan Jumlah Kunjungan

\begin{tabular}{llccc}
\hline No & Jenis pelayanan & \multicolumn{3}{c}{ Jumlah kunjungan } \\
\cline { 3 - 5 } & & Th.2014 & Th.2015 & Th.2016 \\
\hline 1. & Poli umum & 4.030 & 4.252 & 4.640 \\
\hline 2. & Poli kb & 3.200 & 3.020 & 3.520 \\
\hline 3. & Poli gigi & 2.640 & 3.250 & 3.560 \\
\hline 4. & P.kes. Ibu dan anak & 2.420 & 2.220 & 2.702 \\
\hline 5. & Laboratorium & 1.420 & 1.225 & 1.480 \\
\hline & Jumlah & 13.710 & 13.967 & 15.902 \\
\hline
\end{tabular}

Sumber Data:UPT Puskesmas Balai Makam Tahun 2017

Isu pelayanan publik merupakan isu yang hangat untuk diperbincangkan disaat pemerintah sedang berbenah memperbaiki pelayanan untuk warganegaranya (Dwiyanto, A, 2018). Banyaknya permasalahanpermasalahan didaerah mengenai pelayanan publik, khususnya pelayanan kesehatan yang diberikan puskesmas (Rijal, F., Dangnga, M. S., Usman, 2019)(Sari, 2019). Begitu juga UPT Puskesmas Balai Makam dalam melaksanakan pemberian pelayanan masih ditemukannya gejala-gejala seperti masih adanya sarana dan prasarana yang belum dipenuhi sesuai dengan standar yang telah ditetapkan, berdasarkan observasi yang dilakukan terlihat belum maksimalnya pemenuhan sarana dan prasarana seperti tabel berikut:

Tabel 2 : Sarana Dan Prasarana Pelayanan

\begin{tabular}{|c|c|c|c|c|c|}
\hline \multirow[t]{2}{*}{ No } & \multirow[t]{2}{*}{ Saranan dan prasarana } & \multirow{2}{*}{$\begin{array}{c}\text { Sesuai permenkes no } 75 \\
\text { tahun } 2014\end{array}$} & \multirow[t]{2}{*}{ Jumlah persediaan } & \multicolumn{2}{|c|}{ Kondisi } \\
\hline & & & & Baik & Rusak \\
\hline 1 & Ambulance & 1 unit & 1 unit & 1 & - \\
\hline 2 & Anuskop & 8 buah & 8 buah & 7 & 1 \\
\hline 3 & Baki logam tempat alat steril bertutup & 7 buah & 7 buah & 5 & 2 \\
\hline 4 & Bingkai uji coba untuk pemeriksaan refraksi & 1 unit & 3 unit & 3 & - \\
\hline 5 & Computer & 5 unit & 5 unit & 3 & 2 \\
\hline 6 & Corong telinga ukuran kecil, sedang, besar & 6 buah & 3 buah & 3 & - \\
\hline 7 & Emesis basin/nierbeken besar & 3 buah & 3 buah & 3 & - \\
\hline 8 & Forceps aligator & 4 buah & 4 buah & 3 & 1 \\
\hline 9 & Garputala $512 \mathrm{hz},, 2084 \mathrm{hz}$ & 10 unit & 10 unit & 8 & 2 \\
\hline 10 & Gunting pembuka jahitan & 3 buah & 3 buah & 2 & 1 \\
\hline 11 & Implant kit & 2 buah & 2 buah & 1 & 1 \\
\hline 12 & Kendaraan roda dua untuk penyuluhan & 6 unit & 6 unit & 3 & 3 \\
\hline 13 & Kursi gigi & 2 unit & 2 unit & 2 & - \\
\hline 14 & Kursi roda & 3 unit & 1 unit & - & 1 \\
\hline 15 & Kursi ruang tunggu & 20 buah & 6 buah & 6 & - \\
\hline 16 & Lemari arsip & 6 unit & 4 unit & 4 & - \\
\hline 17 & Lemari imunisasi & 1 unit & 1 unit & 1 & - \\
\hline 18 & Lemari obat & 4 unit & 4 unit & 3 & 1 \\
\hline 19 & Mobil puskesmas keliling & 1 unit & 1 unit & 1 & - \\
\hline 20 & Opthalmoscope & 3 buah & 3 buah & 3 & - \\
\hline 21 & Pengukur panjang bayi & 2 buah & 2 buah & 1 & 1 \\
\hline 22 & Pincet anatomi & 4 buah & 4 buah & 4 & - \\
\hline 23 & Printer & 2 unit & 2 unit & 2 & - \\
\hline 24 & Sarung bantal & 10 buah & 10 buah & 10 & - \\
\hline 25 & Set tang pencabutan gigi dewasa & 10 unit & 8 unit & 8 & - \\
\hline 26 & Set tang pencabutan gigi anak & 8 unit & 7 unit & 7 & - \\
\hline 27 & Spekulum hidung dewasa & 2 buah & 2 buah & 2 & - \\
\hline 28 & Sterilisator kering & 2 buah & 2 buah & 2 & - \\
\hline 29 & Stetoscope & 3 buah & 6 buah & 6 & - \\
\hline
\end{tabular}




\begin{tabular}{|c|c|c|c|c|c|}
\hline 30 & Sphymomanometer & 5 buah & 9 buah & 9 & - \\
\hline 31 & Tabung oksigen dan regulator & 5 buah & 5 buah & 3 & 2 \\
\hline 32 & Tempat tidur periksa & 6 unit & 6 unit & 6 & - \\
\hline 33 & Tensimeter digital & 6 buah & 6 buah & 6 & - \\
\hline 34 & Tensimeter air raksa & 2 buah & 2 buah & 2 & - \\
\hline 35 & Timbangan bayi & 2 buah & 2 buah & 1 & 1 \\
\hline 36 & Timbangan dewasa & 4 buah & 2 buah & 1 & 1 \\
\hline
\end{tabular}

Sumber Data:UPT Puskesmas Balai Makam Tahun 2017

Observasi serta wawancara yang dilakukan dengan pasien ditemukannya pembayaran yang belum sesuai dengan standar yang ditetapkan Perbup Bengkalis No. 75 Tahun 2016 Tentang Tarif Pelayanan Kesehatan di UPT Puskesmas dan Jaringannya di Wilayah Kabupaten Bengkalis sebagai berikut:

Tabel 3 : Tarif Pelayanan Pada Upt Puskesmas Balai Makam

\begin{tabular}{|c|c|c|c|}
\hline No & Jenis pelayanan & \multicolumn{2}{|c|}{ Tarif } \\
\hline \multirow[t]{2}{*}{1} & Poli umum & & \\
\hline & Pemeriksaan & $\mathrm{Rp}$ & 3,000 \\
\hline \multirow[t]{4}{*}{2} & Poli kb & & \\
\hline & a. Pelayanan suntik kb & $\mathrm{Rp}$ & 15,000 \\
\hline & b. Pemasangan implant & $\mathrm{Rp}$ & 100,000 \\
\hline & c. Pemasangan iud & $\mathrm{Rp}$ & 100,000 \\
\hline \multirow[t]{5}{*}{3} & Poli gigi & & \\
\hline & a. Pencabutan gigi susu perbatang & $\mathrm{Rp}$ & 5,000 \\
\hline & b. Pencabutan gigi tetap perbatang & $\mathrm{Rp}$ & 15,000 \\
\hline & c. Penambalan tetap gigi susu perbatang & $\mathrm{Rp}$ & 3,000 \\
\hline & d. Penambalan tetap gigi permanen perbatang & $\mathrm{Rp}$ & 17,500 \\
\hline \multirow[t]{4}{*}{4} & Pelayanan kesehatan ibu dan anak & & \\
\hline & a. Pemeriksaan & $\mathrm{Rp}$ & 3,000 \\
\hline & b. Pemeriksaan ibu hamil & $\mathrm{Rp}$ & 25,000 \\
\hline & c. Injeksi imunisasi tt & $\mathrm{Rp}$ & 25,000 \\
\hline \multirow[t]{5}{*}{5} & Laboratorium & & \\
\hline & a. Pemeriksaan darah rutin & $\mathrm{Rp}$ & 2,000 \\
\hline & b. Pemeriksaan urine rutin & $\mathrm{Rp}$ & 2,000 \\
\hline & c. Pemeriksaan golongan darah & $\mathrm{Rp}$ & 5,000 \\
\hline & d. Bta & $\mathrm{Rp}$ & 5,000 \\
\hline
\end{tabular}

Sumber data :upt puskesmas balai makam tahun 2017

Serta masih belum lengkapnya pemenuhan ketersediaan obat-obatan yang diperlukan bagi masyarakat

Tabel 4 : Pemakain Dan Lembar Permintaan Obat (Plpo) Tahun 2016

\begin{tabular}{clccc}
\hline No & \multicolumn{1}{c}{ Nama obat } & Satuan & Persediaan & Kebutuhan \\
\hline $\mathbf{1}$ & Asam askorbat (vit c) $50 \mathrm{mg}$ tablet & Tablet & 5.291 & 5.497 \\
\hline $\mathbf{2}$ & Allopurinol tablet 100 mg & Tablet & 3.324 & 3.765 \\
\hline $\mathbf{3}$ & $\begin{array}{l}\text { Anti bakteri doen saleb kombinasi } \\
\text { :basitrasin 500 iu/g+polimiksin 10.000 iu/g }\end{array}$ & Tube & 4.457 & 3.897 \\
& & & \\
$\mathbf{4}$ & Asam asetisalisilat tablet 100 mg & Tablet & 6.897 & 4367 \\
\hline $\mathbf{5}$ & Furosemid tablet 40 mg & Tablet & 4.765 & 5.298 \\
\hline $\mathbf{6}$ & Hidroklorotiazida tablet 25 mg & Tablet & 8.126 & 7.465 \\
\hline $\mathbf{7}$ & Kalsium laktat (kalk) tablet 500 mg & Tablet & 9.234 & 7.253 \\
\hline $\mathbf{8}$ & Kloramfenikol kapsul 250 mg & Kapsul & 1.235 & 1.398 \\
\hline
\end{tabular}




\begin{tabular}{rlccc}
\hline $\mathbf{9}$ & Magnesium sulfat inj (iv) $20 \%-25 \mathrm{ml}$ & Vial & 3.543 & 3.765 \\
\hline $\mathbf{1 0}$ & Mebendazol tablet $100 \mathrm{mg}$ & Tablet & 2.435 & 1.298 \\
\hline $\mathbf{1 1}$ & Metilergometrin maleat (metilergometrin) & Tablet & 6.376 & 6.254 \\
& Tablet salut $0,125 \mathrm{mg}$ & & & \\
\hline $\mathbf{1 2}$ & Natrium bikarbonat tablet $500 \mathrm{mg}$ & Tablet & 1.876 & 2.654 \\
\hline $\mathbf{1 3}$ & Reserpin tablet $0,25 \mathrm{mg}$ & Tablet & 2.876 & 2.987 \\
\hline $\mathbf{1 4}$ & Propillitiourasil tablet $100 \mathrm{mg}$ & Tablet & 2.765 & 1.356 \\
\hline $\mathbf{1 5}$ & Serum anti tetanus injeksi $1.500 \mathrm{iu} /$ ampul & Ampul & 8.654 & 7.564 \\
\hline $\mathbf{1 6}$ & Primakuin tablet $15 \mathrm{mg}$ & Tablet & 4.324 & 3.855 \\
\hline $\mathbf{1 7}$ & Paracetamol sirup $120 \mathrm{mg} / 15 \mathrm{ml}$ & Botol & 1.824 & 2.736 \\
\hline $\mathbf{1 8}$ & Paracetamol $100 \mathrm{mg}$ & Tablet & 4.144 & 2.789 \\
\hline $\mathbf{1 9}$ & Paracetamol tablet $500 \mathrm{mg}$ & Tablet & 13.464 & 14.321 \\
\hline $\mathbf{2 0}$ & Amoksilin kapsul $500 \mathrm{mg}$ & Kapsul & 2.155 & 2.628 \\
\hline $\mathbf{2 1}$ & Erytromycin kapsul $250 \mathrm{mg}$ & Kapsul & 1.378 & 2.512 \\
\hline $\mathbf{2 2}$ & Erytromycin sirup & Botol & 2.146 & 3.157 \\
\hline $\mathbf{2 3}$ & Deksametason injeksi $5 \mathrm{mg} / \mathrm{ml}-1 \mathrm{ml}$ & Ampul & 4.261 & 3.242 \\
\hline $\mathbf{2 4}$ & Deksametason tablet $0,5 \mathrm{mg}$ & Tablet & 4.134 & 3.902 \\
\hline $\mathbf{2 5}$ & Cefotaxim injeksi $1,0 \mathrm{gram}$ & Vial & 865 & 550 \\
\hline $\mathbf{2 6}$ & Ciprofloxacin tab $500 \mathrm{mg}$ & Tablet & 2.046 & 3.911 \\
\hline $\mathbf{2 7}$ & Griseofelvin & Pot & 1.530 & 1.597 \\
\hline $\mathbf{2 8}$ & Captopril tab $25 \mathrm{mg}$ & Tablet & 1.139 & 904 \\
\hline $\mathbf{2 9}$ & Captopril tab $12,5 \mathrm{mg}$ & Tablet & 996 & 774 \\
\hline $\mathbf{3 0}$ & Amlodipin $5 \mathrm{mg}$ & Tablet & 662 & 183 \\
\hline $\mathbf{3 1}$ & Amlodipin $10 \mathrm{mg}$ & Tablet & 600 & 105 \\
\hline $\mathbf{3 2}$ & Furosemid injeksi & Ampul & 3.420 & 2.289 \\
\hline $\mathbf{3 3}$ & Antasida doen tablet $400 \mathrm{mg}$ & Tablet & 10.000 & 5.213 \\
\hline $\mathbf{3 4}$ & Ranitidin tab $150 \mathrm{mg}$ & Tablet & 1.670 & 1.421 \\
\hline $\mathbf{3 5}$ & Piroxicam tab $150 \mathrm{mg}$ & Tablet & 1.303 & 939 \\
\hline $\mathbf{3 6}$ & Ibuprofen tablet $200 \mathrm{mg}$ & Tablet & 1.530 & 509 \\
\hline
\end{tabular}

Sumber data :upt puskesmas balai makam tahun 2017

Tujuan dari penelitian ini adalah untuk mengetahui pelaksanaan pelayanan publik dan mengetahui faktor apa saja yang menjadi pendukung serta penghambat dalam pelayanan yang diberikan. Manfaat penelitian ini sebagai masukan bagi UPT Puskesmas yang ada di indonesia khususnya UPT Puskesmas Balai Makam Kecamatan Bathin Solapan Kabupaten Bengkalis dalam memberikan pelayanan kepada masyarakat.

\section{METODE}

Design penelitian menggunakan pendekatan kuantitatif dengan mengedepankan penyebaran kuesioner yang melibatkan responden dari pihak puskesmas sebagai pemberi pelayanan dengan teknik metode sensus sebanyak 22 orang dan melibatkan masyarakat sebagai penerima pelayanan dengan tekhnik sampling insidential yaitu menurut (Sugiyono, 2003) sampling insidental adalah teknik dilakukan berdasarkan kebetulan, yaitu siapa saja yang secara kebetulan (incidental) bertemu sesuai dengan kriteria yang diperlukan sebanyak 78 orang sehingga keseluruhan responden berjumlah 100 orang. Setelah data primer didapat, dianalisa dengan menggunakan statistik deskriptif (Jonathan, 2006) ialah mengacu kepada data yang bersifat mentah dan disajikan dalam bentuk yang lebih mudah di pahami dan ditafsirkan dari data atau angka yang diperoleh dengan menampilkandan menggambarkan dengan menggunakan frekuensi, distribusi persen dan rata-rata(mean). Sedangkan untuk teknik pengukurannya menggunakan rating scale (Pandey, 2015) mengatakan bahwa rating scale ialah alat digunakan untuk menyatakan 
pendapat atau penilaian mengenai beberapa situasi, objek atau karakter yang di ekspresikan dengan skala nilai yang dapat dikuantifikasikan.

\section{HASIL DAN PEMBAHASAN}

\section{Tangibles}

Usaha yang dilakukan puskesmas dengan mengoptimalkan seluruh sumber daya yang dimiliki secara fisik yang seperti fasilitas layanan,peralatan/perlengkapan, sumber daya manusia yang dimiliki dari latar belakang tenaga kesehatan, dan materi komunikasi puskesmas, bukti fisik.

Wujud tangiables ini dapat dilihat latar belakang tenaga kesehatan yang dimiliki, sarana dan prasarana serta kenyamanan ruang tunggu pelayanan. Dari hasil temuan yang dilakukan didapati bahwa :

Tabel 5 : Tanggapan Responden Tentang Tangibles

\begin{tabular}{clc}
\hline No & \multicolumn{1}{c}{ Sub indikator } & Jumlah skor \\
\hline $\mathbf{1 .}$ & $\begin{array}{l}\text { Adanya latar belakang tenaga kesehatan } \\
\text { yang mendukung dalam melayani } \\
\text { masyarakat. }\end{array}$ & $\mathbf{2 9 3}$ \\
\hline $\mathbf{2 .}$ & $\begin{array}{l}\text { Adanya sarana dan prasarana yang lengkap } \\
\text { dalam memberikan pelayanan. }\end{array}$ & $\mathbf{2 1 3}$ \\
\hline $\mathbf{3}$. & $\begin{array}{l}\text { Adanya kenyamanan ruang tunggu pada } \\
\text { upt puskesmas balai makam kecamatan } \\
\text { mandau kabupaten bengkalis. }\end{array}$ & $\mathbf{2 3 2}$ \\
\hline & \multicolumn{2}{c}{ Total skor }
\end{tabular}

Sumber Data : Hasil Olahan Angket Tahun 2018

\section{Reliability}

Pelayanan yang diberikan secara handal dengan didukung oleh pengetahuan, keahlian, kemandirian serta kemampuan menguasai kerja dan mengedepankan sikap profesionalisme yang tentunya menghasilkan kepuasan bagi penerima pelayanan.

Wujud reability dapat dilihat dari standar pelayanan yang diberikan, kecermatan serta keahlian dalam bidang profesinya. Dari hasil temuan penelitian didapati bahwa :

Tabel 6 : Tanggapan Responden Tentang Reability

\begin{tabular}{clc}
\hline No & \multicolumn{1}{c}{ Sub indikator } & $\begin{array}{c}\text { Jumlah } \\
\text { skor }\end{array}$ \\
\hline $\mathbf{1 .}$ & $\begin{array}{l}\text { Adanya pelayanan yang diberikan } \\
\text { berdasarkan standar pelayanan }\end{array}$ & $\mathbf{2 8 4}$ \\
\hline $\mathbf{2 .}$ & $\begin{array}{l}\text { Terdapatnya kecermatan pegawai } \\
\text { dalam melayani masyarakat. }\end{array}$ & $\mathbf{2 7 2}$ \\
\hline $\mathbf{3 .}$ & $\begin{array}{l}\text { Terdapatnya keahlian pegawai dalam } \\
\text { melayani masyarakat dalam proses } \\
\text { pelayanan }\end{array}$ & $\mathbf{2 7 7}$ \\
\hline \multicolumn{1}{c}{ Total skor } & $\mathbf{8 3 3}$ \\
\hline Sumber Data : Hasil Olahan Angket Tahun 2018
\end{tabular}




\section{Responsiveness}

Kemampuan daya tanggap yang dimiliki oleh pemberi pelayanan untuk melayani masyarakat sesuai dengan tingkat penyerapan, pengertian, ketidaksesuaian atas berbagai hal bentuk pelayanan yang tidak diketahuinya. Berbedanya latar belakang dari masyarakat tentunya memerlukan kebijaksanaan yang bersifat membina, mengarahkan serta pemberian pengertian yang baik agar direspon dan di ikuti oleh masyarakat dalam keperluannya akan pelayanan yang diberikan.

Wujud yang dilakukan seperti diterimanya keluhan-keluhan yang disampaikan masyarakat, dan adanya tanggapan yang dilakukan pegawai serta segera menyelesaikan masalah tersebut. Dari hasil temuan penelitian didapati bahwa

\begin{tabular}{llc}
\multicolumn{3}{l}{ Tabel 7 : Tanggapan Responden Tentang Responsiveness } \\
\hline No & \multicolumn{1}{c}{ Sub indikator } & Jumlah skor \\
\hline 1. & $\begin{array}{l}\text { Aaparatur yang memberikan } \\
\text { pelayanan dengan cepat,tepat dan } \\
\text { cermat sesuai dengan waktu yang } \\
\text { ditentukan. }\end{array}$ & $\mathbf{2 6 2}$ \\
\hline 2. & $\begin{array}{l}\text { Tanggap terhadap keluhan } \\
\text { masyarakat. }\end{array}$ & $\mathbf{2 7 9}$ \\
\hline 3. & $\begin{array}{l}\text { Menyelesaikan permasalahan } \\
\text { terhadap keluhan yang disampaikan } \\
\text { oleh masyarakat }\end{array}$ & $\mathbf{2 8 1}$ \\
\hline & \multicolumn{1}{c}{ Total skor } \\
Sumber & $\mathbf{8 2 2}$ \\
\multicolumn{3}{l}{ Data Hasil Olahan Angket Tahun 2018}
\end{tabular}

\section{Assurance}

Kepastian akan pelayanan yang diberikan kepada masyarakat dilakukan dengan memaksimalkan pelaksanaan komunikasi, kredibilitas, keamanan serta kompetensi dari pegawai pemberi pelayanan yang tentunya memberikan pelayanan yang berkualitas hingga dapat memberikan kepuasan bagi penerima pelayanan.

Wujud assurance yang dilakukan seperti adanya jaminan ketepatan waktu yang dilakukan dan diberikan jaminan legalitas dalam layanan serta dilakukannya penjaminan dalam kepastian biaya yang dikeluarkan untuk menerima sebuah pelayanan. Dari hasil temuan penelitian didapati bahwa:

Tabel 8 : Tanggapan Responden Tentang Assurance

\begin{tabular}{clc}
\hline No & \multicolumn{1}{c}{ Sub indikator } & Jumlah skor \\
\hline 1. & Memberikan jaminan tepat waktu & $\mathbf{2 2 5}$ \\
\hline $\mathbf{2}$. & $\begin{array}{l}\text { Memberikan jaminan legilitas } \\
\text { dalam pelayanan. }\end{array}$ & $\mathbf{2 9 2}$ \\
\hline 3. & $\begin{array}{l}\text { Memberikan jaminan kepastian } \\
\text { biaya dalam pelayanan }\end{array}$ & $\mathbf{2 1 2}$ \\
\hline & $\quad$ Total skor & $\mathbf{7 2 9}$ \\
\hline
\end{tabular}

Sumber Data : Hasil Olahan Angket Tahun 2018

\section{Emphaty}

Sikap mampu memahami masyarakat yang dilayani secara penuh perhatian, simpatik dan memberikan perhatiaan terhadap permasalahan yang dihadai oleh para penerima pelayanan. 
Wujud emphaty dapat dilihat dari pegawai yang melayani kepentingan masyarakat, keramah tamahan serta diberikannya pelayanan secara adil dan bijaksana

Tabel 9 : Tanggapan Responden Tentang Assurance

\begin{tabular}{clc}
\hline No & \multicolumn{1}{c}{ Sub indikator } & Jumlah skor \\
\hline $\mathbf{1 .}$ & $\begin{array}{l}\text { Melayani kepentingan masyarakat } \\
\text { dalam pelayanan }\end{array}$ & $\mathbf{2 8 5}$ \\
\hline $\mathbf{2 .}$ & $\begin{array}{l}\text { Adanya egawai yang melayani } \\
\text { dengan sikap ramah. }\end{array}$ & $\mathbf{2 8 3}$ \\
\hline 3. & $\begin{array}{l}\text { Melayani dengan tidak } \\
\text { diskriminatif }\end{array}$ & $\mathbf{2 8 4}$ \\
\hline \multicolumn{1}{c}{ Total skor } & $\mathbf{8 5 2}$ \\
Sumber Data: Hasil Olahan Agket Tahun 2018 &
\end{tabular}

Sehingga diperoleh hasil rekapitulasi jawaban responden sebagai berikut

Tabel 10: Rekapitulasi Jawaban Responden

\begin{tabular}{clc}
\hline No & \multicolumn{1}{c}{ Indikator } & Skor \\
\hline 1. & Tangibles & 738 \\
\hline 2. & Reliability & 833 \\
\hline 3. & Responsiveness & 822 \\
\hline 4. & Assurance & 729 \\
\hline 5. & Emphaty & 852 \\
\hline & Total skor & 3.974
\end{tabular}

Sumber Data : Hasil Olahan Agket Tahun 2018

Diperoleh skor Tangibles sebanyak 738, Reliabilty diperoleh skor sebanyak 833, Responsiveness diperoleh skor sebanyak 822, Assurance diperoleh skor sebanyak 729, dan Emphaty diperoleh skor sebanyak 852, sehingga total skor untuk keseluruhan indikator yaitu 3.974. Untuk lebih jelasnya dapat dilihat pada garis kontinum berikut:

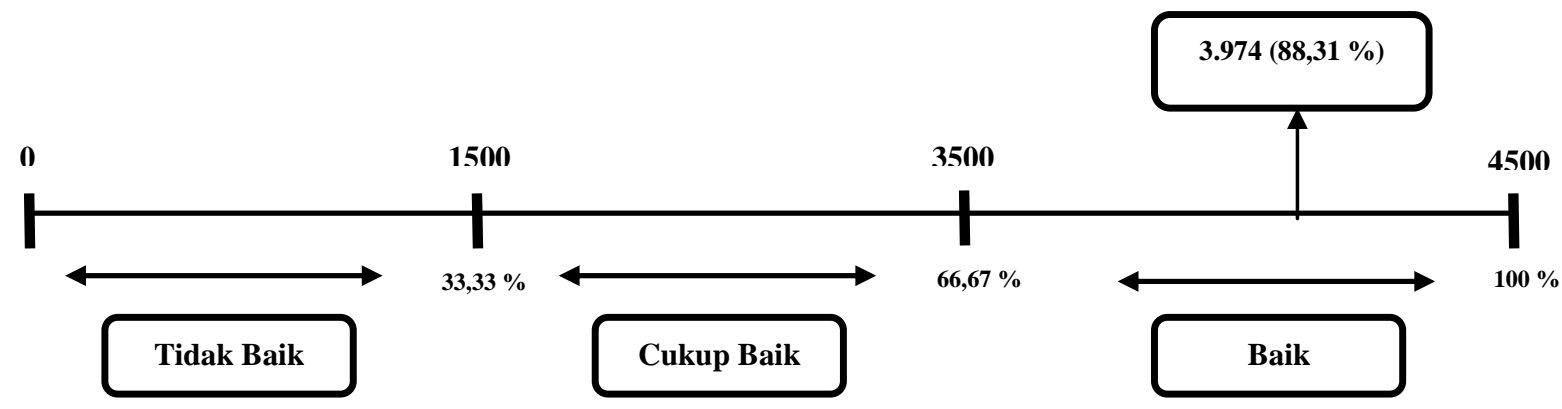

\section{KESIMPULAN}

Hasil penelitian yang dilakukan terhadap 5 (lima) indikator yaitu, tangibles, reliability, responsiveness, assurance, emphaty diperoleh total skor secara keseluruhan sebanyak 3.974 (88,31\%), berada pada kategori baik berada pada rentang skor antara $3.500-4.500$. Faktor pendukung dalam 
penelitian ini ialah (1). Adanya kepedulian pegawai dalam melayani kepentingan masyarakat (2). Pelayanan yang diberikan telah berdasarkan standar pelayanan yang menjadi tolak ukur yang diberikan oleh upt puskesmas dalam rangka pelayanan yang berkualitas, cepat, mudah, dan terjangkau. Sedangkan faktor penghambat (1).kurangnya jaminan kepastian biaya dalam pelayanan (2). Kurangnya ketersediaan sarana dan prasarana dalam mendukung proses pelayanan publik pada upt puskesmas balai makam kecamatan bathin solapan kabupaten bengkalis.

\section{DAFTAR PUSTAKA}

[1]. Afrizal, D. (2018). Analisis Kinerja Birokrasi Publik pada Dinas Sosial Kota Dumai, 13(April), 5362. https://doi.org/https://doi.org/10.31258/sorot.13.1.5655

[2]. Afrizal, D., \& Sahuri, C. (2012). Analisis Manajemen Pelayanan Publik. Jurnal Administrasi Pembangunan, 1(1), 47-50.

[3]. Arifin, M. Z., \& Abidin, A. Z. (2019). Profesionalisme Dalam Meningkatkan Kinerja Terhadap Kualitas Pelayanan Publik ( Studi Kasus di Kantor Kecamatan Lowokwaru Kota Malang ) ISSN 2302-8432, 13(2), 24-32. Retrieved from http://riset.unisma.ac.id/index.php/rpp/article/view/2111

[4]. Hermanto, D. L. \& N. (2018). The effect of service quality toward public satisfaction and public trust on local government in Indonesia. International Journal of Social Economics. Retrieved from https://www.emeraldinsight.com/doi/abs/10.1108/IJSE-04-2017-0151

[5]. Jonathan, S. (2006). Metode Penelitian Kuantitatif \& Kualitatif (Edisi Pert). Yogyakarta: Graha Ilmu.

[6]. Lowokwaru, D., Malang, K., \& Widodo, R. P. (2019). Kualitas Pelayanan Publik Pada Pelayanan Kependudukan Dan Catatan Sipil Di Kantor Keluran Dinoyo Kecamatan Lowokwaru Kota Malang (Studi Kasus Pada Kantor Kelurahan Dinoyokecamatan Lowokwaru Kota Malang), 13(2), 75-82.

[7]. Pandey, M. (2015). Research Methodology:Toola And Techniques (1st ed.). Romania: Bridge Center.

[8]. Parasuraman, A., Zeithaml, V. A., \& Berry, L. L. (1994). Reassessment of Expectations as a Comparison Standard in Measuring Service Quaiity: implications for Furtiier Research, 58(January), 111-124.

[9]. Regah, R. T., Sabijono, H., \& Pinatik, S. (2019). Analisis Pendidikan, Pengalaman Kerja Dan Pelatihan Pada Pelayanan Aparatur Pajak Di Uptd Samsat Amurang, 14(1), 64-72. Retrieved from https://ejournal.unsrat.ac.id/index.php/gc/article/view/22288

[10]. Rijal, F., Dangnga, M. S., Usman. (2019). Pengaruh Etika Dan Kinerja Tenaga Kesehatan Terhadap Pemberian Pelayanan Kesehatan Pasien Di Puskesmas Madising Na Mario Kota Parepare. Jurnal Ilmiah Manusia Dan Kesehatan, 2(1), 12-25. Retrieved from http://jurnal.umpar.ac.id/index.php/makes

[11]. Sari, D. (2019). Pelayanan Publik Padapusat Kesehatanmasyarakat Di Kecamatan Tampan Kota 
Pekanbaru Tahun 2017. Jurnal Online Mahasiswa (JOM) Bidang Ilmu Sosial Dan Ilmu Politik, 6(1), 1-15. Retrieved from https://jom.unri.ac.id/index.php/JOMFSIP/article/view/22933 